\title{
Antimalarial potential of quinones isolated from plants: an integrative review
}

\author{
Potencial antimalárico de quinonas isoladas de plantas: uma revisão integrativa \\ Potencial antipalúdico de quinonas aislados de plantas: una revision integradora
}

Received: 01/30/2021 | Reviewed: 02/07/2021 | Accept: 02/10/2021 | Published: 02/20/2021

\author{
Antonio Rafael Quadros Gomes \\ ORCID: https://orcid.org/0000-0002-4700-7942 \\ Universidade Federal do Pará, Brazil \\ E-mail: rafaelquadros13@hotmail.com \\ Heliton Patrick Cordovil Brígido \\ ORCID: https://orcid.org/0000-0002-8472-2179 \\ Universidade Federal do Pará, Brazil \\ E-mail: Helitom2009@hotmail.com \\ Valdicley Vieira Vale \\ ORCID: https://orcid.org/0000-0001-6570-4875 \\ Universidade Federal do Pará, Brazil \\ E-mail: valdicleyvale@gmail.com \\ Juliana Correa-Barbosa \\ ORCID: https://orcid.org/0000-0002-8814-3190 \\ Universidade Federal do Pará, Brazil \\ E-mail: correabjuliana@gmail.com \\ Sandro Percário \\ ORCID: https://orcid.org/0000-0002-9528-0361 \\ Universidade Federal do Pará, Brazil \\ E-mail: percario@ufpa.br \\ Maria Fâni Dolabela \\ ORCID: https://orcid.org/0000-0003-0804-5804 \\ Universidade Federal do Pará, Brazil \\ E-mail: Fanidolabela20@gmail.com
}

\begin{abstract}
Antimalarial treatment is often associated with the resistance developed by Plasmodium which generate ineffective drug treatment. Based on this, the search for therapeutic alternatives is necessary and urgent. This review intends to assess the antimalarial potential of quinones isolated from plants. The search for scientific articles was carried out on the CAPES Journal Portal (PPC), Virtual Health Library (VHL), PUBMED, NCBI and SCIELO, using the following descriptors: quinones and antimalarials. Inclusion criteria were adopted based on studies about quinones isolated from plants and tested against Plasmodium falciparum and Plasmodium berghei. The exclusion criteria were based mainly on articles that tested extracts, fractions and synthesis of quinones obtained from plants and other natural products. A total of 1344 publications were collected for screening $(\mathrm{PPC}=5, \mathrm{VHL}=248, \mathrm{PUBMED}=525, \mathrm{NCBI}=462$ and SCIELO = 94). From this total, 1280 articles were excluded, with only 64 articles selected for full reading. All benzoquinones were active against $P$. falciparum. Naphthoquinones were active, inactive and moderately active against the $P$. falciparum e $P$ berghei. Anthraquinones and anthrones were active and moderately active against $P$. falciparum. The naphthoquinone 2-acetylnaphtho- [2,3b] -furan-4,9-dione was the most active of all the molecules tested against Plasmodium. Whereas lapachol was the most studied naphthoquinone and structural changes do not seem to contribute to the activity. In summary, quinones are promising as antimalarials, however, need in vivo studies.
\end{abstract} Keywords: Quinones; Plasmodium; Antimalarials; Plants.

\section{Resumo}

O tratamento antimalárico frequentemente está associado aos fatores de resistência desenvolvidos pelo Plasmodium e que geram ineficácia do tratamento medicamentoso. Baseado nisso, a busca por novas alternativas terapêuticas é necessária e urgente. O objetivo desta revisão é avaliar o potencial antimalárico de quinonas isoladas de plantas. A busca de artigos científicos foi realizada no Portal de Periódicos CAPES (PPC), Biblioteca Virtual em Saúde (BVS), PUBMED, NCBI e SCIELO, sendo os descritores utilizados: quinonas e antimaláricos. Foram adotados os critérios de inclusão baseados em estudos sobre quinonas isoladas de plantas e testadas contra o Plasmodium falciparum e Plasmodium berghei. Em relação aos critérios de exclusão, foram baseados principalmente em artigos que testaram extratos, frações e síntese de quinonas obtidas de plantas e outros produtos naturais. Um total de 1344 publicações foi coletado para triagem $(\mathrm{PPC}=5, \mathrm{BVS}=248, \mathrm{PUBMED}=525, \mathrm{NCBI}=462$ e SCIELO $=94)$. Deste total, foram excluídos 1.280 artigos, sendo selecionados somente 64 artigos para leitura na íntegra. Todas as benzoquinonas foram ativas contra o $P$. falciparum. As naftoquinonas foram ativas, inativas e moderadamente ativas contra o $P$. falciparum 
e P. berghei. Já as antraquinonas e as antronas foram ativas e moderadamente ativas contra o P. falciparum. A naftoquinona2-acetylnaphtho-[2,3b]-furan-4,9-dione foi a mais ativa dentre todas as moléculas testadas contra o Plasmodium. Enquanto, o lapachol foi a naftoquinona mais estudada e mudanças estruturais parecem não contribuir para a atividade. Em síntese, as quinonas são promissoras como antimaláricos, entretanto, são necessários estudos in vivo.

Palavras-chave: Quinonas; Plasmodium; Antimaláricos; Plantas.

\section{Resumen}

El tratamiento antimalárico suele asociarse a los factores de resistencia desarrollados por Plasmodiumy que generan un tratamiento farmacológico ineficaz. En base a esto, la búsqueda de nuevas alternativas terapéuticas es necesaria y urgente. El propósito de esta revisión es evaluar el potencial antipalúdico de las quinonas aisladas de plantas. La búsqueda de artículos científicos se realizó en el Portal de Revistas CAPES (PPC), Biblioteca Virtual en Salud (BVS), PUBMED, NCBI y SCIELO, con los descriptores utilizados: quinonas y antimaláricos. Los criterios de inclusión se adoptaron basándose en estudios sobre quinonas aisladas de plantas y probadas contra Plasmodium falciparum e Plasmodium berghei. En cuanto a los criterios de exclusión, se basaron principalmente en artículos que probaron extractos, fracciones y síntesis de quinonas obtenidas de plantas y otros productos naturales. Se recopilaron 1344 publicaciones para cribado $(\mathrm{PPC}=5, \mathrm{VHL}=248, \mathrm{PUBMED}=525, \mathrm{NCBI}=462$ y SCIELO $=94)$. De este total, se excluyeron 1.280 artículos, con solo 64 artículos seleccionados para lectura completa. Todas las benzoquinonas fueron activas contra $P$. falciparum. Las naftoquinonas fueron activas, inactivas y moderadamente activas contra el $P$. falciparum e $P$. berghei. Las antraquinonas y antronas fueron activas y moderadamente activas contra $P$. falciparum. La naftoquinona 2-acetilnafto- [2,3b] -furan-4,9-diona fue la más activa entre todas las moléculas probadas contra Plasmodium, considerándose la más prometedora en el desarrollo de fármacos futuros. Mientras que el lapachol fue la naftoquinona más estudiada y los cambios estructurales no parecen contribuir a la actividad. En resumen, las quinonas son prometedoras como antipalúdicos, sin embargo, necesitan estudios in vivo.

Palabras clave: Quinonas; Plasmodium; Antimaláricos; Plantas.

\section{Introduction}

About 3.3 billion people are exposed to malaria in endemic areas at risk of contracting the disease in more than 100 countries. In 2018 there were 228 million cases of malaria, with the African continent having the highest morbidity rate with 213 million cases, and almost 1 million deaths (WHO, 2019). In the Americas, 138 million people live in risk areas. The Venezuela, Brazil, Peru, Nicaragua and Colombia are the countries with the highest number of cases and deaths (OPAS, 2020).

The widespread increase in resistance to antimalarial drugs is one of the main problems in reducing the mortality caused by Plasmodium, which results in delay or failure of remission of blood forms, allowing the selection of resistant gametocytes. Resistance to antimalarials is associated with the irrational use of medicines, counterfeit drugs, long drug halflives, host immunity, parasite and environmental factors (Winstanley, 2001). In addition to quinine and chloroquine, resistance to primaquine, proguanil, atovacone, mefloquine and combined artemisinin therapy (Wongsrichanalai et al., 2002; Noeldl et al., 2008; Van Bong et al., 2014) has been reported.

Based on this, there is a search for new drugs that are more selective, less toxic and do not induce resistance in Plasmodium (Gamo et al., 2010; Penna-Coutinho et al., 2011; Aguiar et al., 2012; Coutinho et al., 2013; Souza et al., 2014). One of the new strategies for creating antimalarial drugs is the characterization and isolation of compounds from medicinal plants, especially quinones such as naphthoquinones, with atovaquone as its main representative, a very active and less toxic naphthoquinone that acts by inhibiting purine biosynthesis in the parasite (Hage et al., 2009; Hughes et al., 2011).

The development of new therapeutic alternatives to treat malaria is necessary, mainly due to the drug resistance of the Plasmodium, therefore, metabolites such as quinones, isolated from medicinal plants have shown promising results as a potential drug in the treatment of infectious diseases such as malaria. The purpose of this literature review is to evaluate the antimalarial potential of quinones isolated from different plant species. 


\section{Methodology}

In this integrative review, a research was carried out to select scientific articles available on the following platforms: CAPES Journal Portal (PPC), Virtual Health Library (VHL), PUBMED, NCBI and SCIELO, without limiting the publication year of articles.

The search period was between August and September 2020, and only articles in Portuguese, English and Spanish were adopted as inclusion criteria, and adaptation of the title to the theme and compatible summary as well.

The exclusion criteria adopted were articles that did not address the topic of study, papers in other languages, articles that tested extracts and fractions, quinones obtained through synthesis and other natural products, articles not available in full, duplicates and studies that have not been analyzed by experts.

The representative descriptors for searching the articles on platforms were quinones and antimalarials. Initially, 1344 were collected for screening $(\mathrm{PPC}=5, \mathrm{VHL}=248, \mathrm{PUBMED}=525, \mathrm{NCBI}=462$ and SCIELO $=94)$. However, after analyzing the title and abstract, 1,280 articles were excluded, with only 64 articles selected for full reading and likely inclusion in the integrative review.

The selection was based on the title and abstract, being carried out by three reviewers who took into account the inclusion and exclusion criteria. In cases of divergences during the selection analysis, a fourth reviewer was consulted to ensure compliance with the study requirements. After reading the articles, 38 were used in the results and 38 were used in the discussion of this review, with 24 articles excluded from the 64 initially included. In addition, to facilitate the organization and tabulation of the data, it was divided into two stages of analysis: first, a table with the title and summary was made. In the second stage, full reading and synthesis of the articles were carried out to produce the results and discussion.

The antimalarial activity of quinones in vitro was considered active when the $\mathrm{IC}_{50}$ was less than or equal to $10 \mu \mathrm{g} . \mathrm{mL}^{-}$ ${ }^{1}$ against the plasmodium; moderately active with an $\mathrm{IC}_{50}$ greater than $10 \mu \mathrm{g} \cdot \mathrm{mL}^{-1}$ and less than $100 \mu \mathrm{g} \cdot \mathrm{mL}^{-1}$ and inactive with an $\mathrm{IC}_{50}$ greater than $100 \mu \mathrm{g} / \mathrm{ml}^{-1}$.

\section{Results and Discussion}

As a causative agent of malaria, Plasmodium is responsible for approximately two million deaths worldwide. In almost all endemic populations, the parasite has developed resistance against drugs used in first-line treatment, such as chloroquine and its derivatives. An important area in antimalarial research is based on finding a potent and reliable antiparasitic medication capable of inhibiting Plasmodium infection and growth (Najera, 2001; Hyde, 2002). In this context, quinones have been increasingly studied, since the antimalarial activity of Atovaquone was described (Basco et al., 1995).

Quinones represent a wide and varied family of compounds found in nature, especially in plants, fungi, lichens and bacteria, and can be synthesized (Thomson, 1971). Based on their molecular structure, quinones can be classified according to the type of aromatic ring that supports the basic quinoid nucleus: benzoquinones (benzene ring), naphthoquinones (naphthalenic ring) and anthraquinones (linear or angular anthracene ring). These three types of quinones are the most frequently found in nature (Silva et al., 2003). When we analyzed the in vitro antimalarial activity of benzoquinones, we found few studies reporting the activity of these compounds against $P$. falciparum (Ichino et al., 2006; Tasdemir et al., 2006; Boonphong et al., 2007; Radwan et al., 2008).

The benzoquinones Primin (1) Marcanine A (2) and Bauhinoxepin I (3) showed activity with $\mathrm{IC}_{50}$ of $2.27 \mu \mathrm{g} \cdot \mathrm{mL}^{-1}$, $2.51 \mu \mathrm{g} \cdot \mathrm{mL}^{-1}$ and $3.0 \mu \mathrm{g} \cdot \mathrm{mL}^{-1}$, respectively (Table 1, Figure 1), while Bauhinoxepin J (4; Figure 1) was active against a chloroquine-resistant strain of $P$. falciparum (k1; $1.48 \mu \mathrm{g} . \mathrm{mL}^{-1}$ ) and 5-acetoxy-6-geranyl-3-npentyl-1, 4-benzoquinone (5) 
showed activity against both sensitive (D6) and resistant (W2) strain to chloroquine with an $\mathrm{IC}_{50}$ of 2.8 and $2.6 \mu \mathrm{g} . \mathrm{mL}^{-1}$, respectively (Table 1, Figure 1).

Kumar, Musiyenko \& Barik (2003) demonstrated that a naturally occurring benzoquinone, geldanamycin, interferes with regulation of the cell cycle and signal transduction through specific inhibition of the Hsp90 protein, in CQ-sensitive and CQ-resistant strains (3D7 and W2, respectively) in all erythrocytic phases of the parasite. Hsp90 is the chaperone responsible for folding and, therefore, for the functioning of many essential proteins for parasite survival (Richter \& Buchner, 2001).

In the present study, from the quinones evaluated against antimalarial activity, naphthoquinones are the most studied subclass. Twenty-eight compounds were tested in different chloroquine-resistant and sensitive strains and from these, nine showed moderate activity and eighteen naphthoquinones were active. It is worth mentioning that, six naphthoquinones (Lapachol; 2-acetylnaphtho-[2,3b]-furan-4,9-dione; Sterekunthal A; 2-(1-hydroxyethyl)-naphtho-[2,3-b]-furan-4,9-quinone; Isopinnatal and Plumbagin) showed high activity with $\mathrm{IC}_{50}$ below $1 \mu \mathrm{g} \cdot \mathrm{mL}^{-1}$ (Table 1; Figure 1). From these, 2-acetylnaphtho[2,3b]-furan-4,9-dione showed high activity when evaluated against $P$. berghei $\left(\mathrm{IC}_{50}=0.002 \mu \mathrm{g} \cdot \mathrm{mL}^{-1}\right)$, and against $P$. falciparum, Plumbagin showed greater activity $\left(\mathrm{IC}_{50}=0.05 \mu \mathrm{g} \cdot \mathrm{mL}^{-1}\right)$. Such results show that naphthoquinones are the most promising against malaria.

One of the most studied naphthoquinones with great antimalarial potential is Atovaquone. It is even used as an alternative therapy in cases of resistance against first-line drugs, and for malaria prophylaxis. Due to the quinonic nature of the compounds evaluated in the present study, and the structural similarity of naphthoquinones with Atovaquone, the antimalarial activity of these compounds may be related to the inhibition of parasite's mitochondrial cytochrome bc1 complex, interrupting electron transport and consequently the synthesis of pyrimidines and, therefore, preventing the replication of the parasite's DNA (Birth et al., 2014). Just to clarify, a study showed that Atovaquone binds to the mitochondrial bc1 complex inhibiting the electron transport system in the apicoplast (Waller \& McFadden, 2005).

In an antimicrobial and cytotoxicity study of Eleutherine bulbosa, a plant rich in quinones, identified activity of the extracts and fractions for Staphylococcus aureus, however the fractionation contributed to the increase in cytotoxicity (Borges et al., 2020). In a similar study, do Nascimento Brandão et al. (2020) evaluated the antimalarial and toxicity activity of Aspidosperma nitidum and demonstrated that the extracts and fractions showed high activity for P. falciparum (strain W2) in vitro and action against $P$. berghei in infected mice. In addition, the extracts and fractions showed low toxicity, both in vitro and in vivo. Da Veiga et al. (2020) also identified that metabolites isolated from plants are effective in destroying parasites in vitro.

When we analyze the antimalarial activity of anthraquinones, we observe that it is the second most studied subclass of quinones. A total of 17 anthraquinones were evaluated to assess their antimalarial potential, from these 15 substances presented $\mathrm{IC}_{50}$ below $10 \mu \mathrm{g} \cdot \mathrm{mL}^{-1}$, therefore, they were considered active, and we can highlight the 3 most promising substances: Joziknipholone A, Joziknipholone B, Isoknipholone and Knipholoneanthrone that showed high activity against sensitive (3D7) and resistant (K1, D6 and W2) strains of $P$. falciparum with $\mathrm{IC}_{50}$ less than $1 \mu \mathrm{g} \cdot \mathrm{mL}^{-1}$ (Table 1, Figure 1).

During the data analysis about anthrones, we found that only 8 molecules have been evaluated. However, 7 compounds have antimalarial potential, mainly because they showed activity against a chloroquine-resistant strain of $P$.

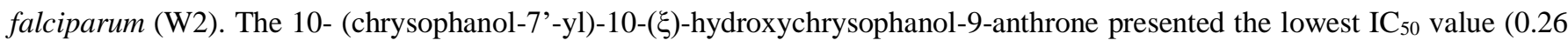
$\mu \mathrm{g} . \mathrm{mL}^{-1}$ ), being the compound with the greatest potential. Another 3 compounds (Bazouanthrone; 3-geranyloxyemodin anthrone and 3-prenyloxyemodin anthrone) also showed high activity, with $\mathrm{IC}_{50}$ below $1 \mu \mathrm{g} \cdot \mathrm{mL}^{-1}$ (Table 1, Figure 1). 
Research, Society and Development, v. 10, n. 2, e38210212507, 2021

(CC BY 4.0) | ISSN 2525-3409 | DOI: http://dx.doi.org/10.33448/rsd-v10i2.12507

Table 1: Antimalarial activity of quinones.

\begin{tabular}{|c|c|c|c|c|}
\hline Name (class) & $\begin{array}{l}\text { Antimalarial activity } \\
\left(\mathrm{IC}_{50} \mu \mathrm{g} \cdot \mathrm{mL}^{-1}\right)\end{array}$ & Plasmodium species (strain) & Data analysis & Reference \\
\hline \multicolumn{5}{|c|}{ Benzoquinones } \\
\hline $\operatorname{Primin}^{1}$ & 2.27 & P. falciparum (K1) & Active & Tasdemir et al., 2006 \\
\hline Marcanine A 2 & 2.51 & P. falciparum (K1) & Active & Ichino et al., 2006 \\
\hline Bauhinoxepin $\mathrm{I}^{3}$ & 3.0 & P. falciparum (K1) & Active & Boonphong et al., 2007 \\
\hline Bauhinoxepin $\mathrm{J}^{4}$ & 1.48 & P. falciparum (K1) & Active & Boonphong et al., 2007 \\
\hline $\begin{array}{l}\text { 5-acetoxy-6-geranyl-3-n-pentyl-1,4- } \\
\text { benzoquinone }\end{array}$ & 2.8 and 2.6 & P. falciparum (D6 and W2) & Active & Radwan et al., 2008 \\
\hline \multicolumn{5}{|c|}{ Naphthoquinones } \\
\hline Eleutherol $^{6}$ & $>200$ & P. falciparum (3D7) & Inactive & Vale et al., 2020 \\
\hline Eleutherin ${ }^{7}$ & $10.45 \pm 3.13$ & P. falciparum (3D7) & Active & \\
\hline Isoeleutherin ${ }^{8}$ & $8.70 \pm 2.45$ & P. falciparum (3D7) & Active & \\
\hline \multirow{8}{*}{ Lapachol $^{9}$} & $2.7 \pm 1$ & P. falciparum & Active & Barbosa et al., 2014 \\
\hline & $0.76 \pm 0,01$ & P. falciparum (BHz26/86) & Active & \\
\hline & $2.28 \pm 0.04$ & P. falciparum (HB3) & Active & de Andrade-Neto et al., 2004 \\
\hline & $0.9 \pm 0.006$ & P. falciparum (D6) & Active & \\
\hline & $0.85 \pm 0.007$ & P. falciparum (W2) & Active & \\
\hline & $46.31 \pm 2.9$ & P. falciparum (W2) & Moderatelyactive & do Nascimento et al., 2020 \\
\hline & $19.47 \pm 4.84$ & P. falciparum (W2) & Moderatelyactive & Moreira et al., 2015 \\
\hline & 1.18 & P. berghei* & Active & Gómez-Estrada et al., 2012 \\
\hline \multirow{2}{*}{$\alpha$-lapachone $\mathrm{e}^{\mathbf{1 0}}$} & $5.48 \pm 0,55$ & P. falciparum (W2) & Active & do Nascimento et al., 2020 \\
\hline & $3.82 \pm 0.84$ & P. falciparum (W2) & Active & Moreira et al., 2015 \\
\hline \multirow{3}{*}{$\beta$-lapachone ${ }^{11}$} & $>4.84$ & $P$. falciparum & Active & de Andrade-Neto et al., 2004 \\
\hline & $9.16 \pm 0.93$ & P. falciparum (W2) & Active & do Nascimento et al., 2020 \\
\hline & $4.96 \pm 0.24$ & P. falciparum (W2) & Active & Moreira et al.,2015 \\
\hline Diospyrin $^{12}$ & 3.29 & P. falciparum $(\mathrm{K} 1)$ & Active & Theerachayanan et al., 2007 \\
\hline $\begin{array}{l}\text { 2-acetyl-8-methoxy-naphtho-[2,3b]-furan- } \\
\qquad 4,9 \text {-dione } \mathbf{1 3}\end{array}$ & 51.80 & P. berghei* & Moderatelyactive & Gómez-Estrada et al., 2012 \\
\hline $\begin{array}{l}\text { 2-acetyl-7,8-dimethoxy-naphtho-[2,3b]- } \\
\text { furan-4,9-dione }\end{array}$ & 2.96 & P. berghei* & Active & Gómez-Estrada et al., 2012 \\
\hline 2-acetylnaphtho-[2,3b]-furan-4,9-dione ${ }^{15}$ & 0.002 & P. berghei* & Active & Gómez-Estrada et al., 2012 \\
\hline
\end{tabular}


Research, Society and Development, v. 10, n. 2, e38210212507, 2021

(CC BY 4.0) | ISSN 2525-3409 | DOI: http://dx.doi.org/10.33448/rsd-v10i2.12507

2-acetyl-7-hydroxi-8-methoxynaphtho[2,3b]-furan-4,9-dione ${ }^{\mathbf{1 6}}$ Busseihydroquinone $\mathrm{A}^{17}$ Busseihydroquinone $\mathrm{B}^{\mathbf{1 8}}$ Busseihydroquinone $\mathrm{C}^{19}$ Busseihydroquinone $\mathrm{D}^{20}$ Sterekunthal A ${ }^{21}$

Sterekunthal B ${ }^{22}$

Pyranokunthone $\mathrm{A}^{23}$ Pyranokunthone $\mathrm{B}^{\mathbf{2 4}}$

2-(1-hydroxyethyl)naphtho[2,3-b]furan-4,9quinone 25

Isopinnatal $^{26}$

Kigelinol $^{27}$

Isokigelinol $^{28}$

Plumbagin ${ }^{29}$

2-methylnaphthazarin ${ }^{30}$

Octadecylcaffeate ${ }^{31}$

Isoshinanolone $^{\mathbf{3 2}}$

Droserone $\mathrm{D}^{33}$
11.80

$36.03,144.43$

$27.82,126.36$

$32.65,60.08$

$19.59,80.10$

$1.3 \pm 0.1,0.4 \pm 0.1$

$23.3 \pm 4.2$ and $15.2 \pm 1.7$

$11.7 \pm 4.0,>25.0$

$8.9 \pm 1.2,7.8 \pm 1.3$

$0.152 \pm 0.129,0.174 \pm$ 0.061

$0.258 \pm 0.107,0.525 \pm 0.49$

$5.139 \pm 0.921,4.68 \pm 0.896$

$4.048 \pm 0.79,3.679 \pm 1.335$

0.05

1.18

5.08

4.0

4.5
P. berghei*

P. falciparum (D6 and W2)

$P$. falciparum (D6 and W2)

$P$. falciparum (D6 and W2)

P. falciparum (D6 and W2)

$P$. falciparum (poW and Dd2)

$P$. falciparum (poW and Dd2)

P. falciparum (poW and Dd2)

P. falciparum (poW and Dd2)

P. falciparum (K1 and T9-96)

P. falciparum (K1 and T9-96)

$P$. falciparum (K1 and T9-96)

P. falciparum (K1 and T9-96)

P. falciparum (T9/94)

P. falciparum (T9/94)

P. falciparum (T9/94)

P. falciparum(T9/94)

P. falciparum (T9/94)
Moderatelyactive

ModeratelyactiveandInactive

ModeratelyactiveandInactive

Moderatelyactive

Moderatelyactive Active

Moderatelyactive

Moderatelyactive Active

Active

Active

Active

Active

Active

Active

Active

Active

Active
Gómez-Estrada et al., 2012

Endale et al., 2012

Endale et al., 2012

Endale et al., 2012

Endale et al., 2012

Onegi et al., 2002

Onegi et al., 2002

Onegi et al., 2002

Onegi et al., 2002

Weiss et al., 2000

Weiss et al., 2000

Weiss et al., 2000

Weiss et al., 2000

Likhitwitayawuid et al., 1998

Likhitwitayawuid et al., 1998

Likhitwitayawuid et al., 1998

Likhitwitayawuid et al., 1998

Likhitwitayawuid et al., 1998

\begin{tabular}{|c|c|c|c|c|}
\hline \multicolumn{5}{|c|}{ Anthraquinones } \\
\hline Anthrakunthone $\mathrm{A}^{34}$ & $14.7 \pm 0.25,14.7 \pm 5.3$ & P. falciparum (poW and Dd2) & Moderatelyactive & Onegi et al., 2002 \\
\hline $\begin{array}{c}\text { Sodium 4' -O-demethylknipholone 6' -O- } \\
\text { sulfate }^{35}\end{array}$ & 4.13 & P. falciparum $(\mathrm{K} 1)$ & Active & Mutanyatta et al., 2005 \\
\hline \multirow{2}{*}{ Joziknipholone $\mathrm{A}^{36}$} & 0.142 & P. falciparum (K1) & Active & Bringmann et al., 2008 \\
\hline & $0.4 \pm 0.1,0.3 \pm 0.1$ & P. falciparum (D6 and W2) & Active & Induli et al., 2013 \\
\hline \multirow{2}{*}{ Joziknipholone $\mathrm{B}^{37}$} & 0.23 & $P$. falciparum $(\mathrm{K} 1)$ & Active & Bringmann et al., 2008 \\
\hline & $2.5 \pm 0.6,1.5 \pm 0.2$ & P. falciparum (D6 and W2) & Active & Induli et al., 2013 \\
\hline $\begin{array}{l}\text { 10-methoxy-10,7'-(chrysophanolanthrone)- } \\
\text { chrysophanol }{ }^{\mathbf{3 8}}\end{array}$ & $4.07 \pm 1.54,1.17 \pm 0.12$ & P. falciparum (D6 and W2) & Active & Abdissa et al., 2013 \\
\hline \multirow{2}{*}{ Knipholonecyclooxanthrone ${ }^{39}$} & $3.96 \pm 0.70,6.13 \pm 1.59$ & P. falciparum (D6 and W2) & Active & Abdissa et al., 2013 \\
\hline & $4.0 \pm 0.7,6.1 \pm 1.6$ & P. falciparum (D6 and W2) & Active & Induli et al., 2013 \\
\hline
\end{tabular}


Research, Society and Development, v. 10, n. 2, e38210212507, 2021

(CC BY 4.0) | ISSN 2525-3409 | DOI: http://dx.doi.org/10.33448/rsd-v10i2.12507

\begin{tabular}{|c|c|c|c|c|}
\hline 10-acetonylknipholonecyclooxanthrone ${ }^{40}$ & $4.4 \pm 1.5,3.1 \pm 1.2$ & P. falciparum (D6 and W2) & Active & Induli et al., 2013 \\
\hline \multirow{2}{*}{ Knipholoneanthrone ${ }^{41}$} & $4.1 \pm 0.8,3.6 \pm 0.9$ & P. falciparum (D6 and W2) & Active & Induli et al., 2013 \\
\hline & 0.3 & P. falciparum (3D7) & Active & Feilcke et al., 2019 \\
\hline $\begin{array}{l}\text { 10-hydroxy-10-(chrysophanol-7'-yl)- } \\
\text { chrysophanolanthrone }{ }^{42}\end{array}$ & $1.7 \pm 0.2,0.7 \pm 0.2$ & P. falciparum (D6 and W2) & Active & Induli et al., 2013 \\
\hline $\begin{array}{c}\text { 10-methoxy-10-(chrysophanol-7'-yl) } \\
\text { chrysophanolanthrone }\end{array}$ & $4.1 \pm 1.5,1.2 \pm 0.1$ & P. falciparum (D6 and W2) & Active & Induli et al., 2013 \\
\hline \multirow{2}{*}{ Asphodelin $^{44}$} & $8.2 \pm 1.7,6.4 \pm 1.4$ & P. falciparum (D6 and W2) & Active & Induli et al., 2013 \\
\hline & 0.96 & P. falciparum (3D7) & Active & Feilcke et al., 2019 \\
\hline Knipholone $^{45}$ & $10.1 \pm 0.2,8.0 \pm 0.5$ & P. falciparum (D6and W2) & Active & Induli et al., 2013 \\
\hline \multirow{2}{*}{ Isoknipholone ${ }^{46}$} & $8.6 \pm 1.6,7.9 \pm 1.2$ & P. falciparum (D6 and W2) & Active & Induli et al., 2013 \\
\hline & 0.12 & P. falciparum $(\mathrm{K} 1)$ & Active & Mutanyatta et al., 2005 \\
\hline \multirow{2}{*}{ Dianellin $^{47}$} & $5.5 \pm 1.2,3.3 \pm 0.2$ & P. falciparum (D6 and W2) & Active & Induli et al., 2013 \\
\hline & $3.28 \pm 0.19,5.47 \pm 1.20$ & P. falciparum (D6 and W2) & Active & Abdissa et al., 2013 \\
\hline Chrysophanol $^{48}$ & $21.05 \pm 0.64,36.09 \pm 3.32$ & P. falciparum (D6 and W2) & Moderatelyactive & Abdissa et al., 2017 \\
\hline Aloesaponarin I ${ }^{49}$ & $7.80 \pm 1.11,20.13 \pm 5.12$ & P. falciparum (D6 and W2) & Active andModeratelyactive & Abdissa et al., 2017 \\
\hline Aloesaponarin II ${ }^{50}$ & $5.00 \pm 0.36,18.60 \pm 7.10$ & P. falciparum (D6 and W2) & Active andModeratelyactive & Abdissa et al., 2017 \\
\hline \multicolumn{5}{|c|}{ Anthrones } \\
\hline 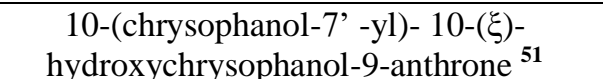 & 0.26 & P. falciparum (D7) & Active & Wube et al., 2005 \\
\hline Bazouanthrone $e^{52}$ & 0.85 & P. falciparum (W2) & Active & Lenta et al., 2007 \\
\hline Glaberianthrone $^{53}$ & 2.10 & P. falciparum (W2) & Active & Lenta et al., 2008 \\
\hline Bianthrone $1^{\text {a } 54}$ & 1.98 & P. falciparum (W2) & Active & Lenta et al., 2008 \\
\hline 3-geranyloxyemodinanthrone ${ }^{55}$ & 0.66 & P. falciparum (W2) & Active & Lenta et al., 2008 \\
\hline 3-prenyloxyemodinanthrone ${ }^{56}$ & 0.64 & P. falciparum (W2) & Active & Lenta et al., 2008 \\
\hline 2-geranylemodin ${ }^{57}$ & 2.17 & P. falciparum (W2) & Active & Lenta et al., 2008 \\
\hline Peperovulcanone $\mathrm{A}^{58}$ & 22.28 & P. falciparum (W2mef) & Moderatelyactive & Ngemenya et al., 2015 \\
\hline
\end{tabular}

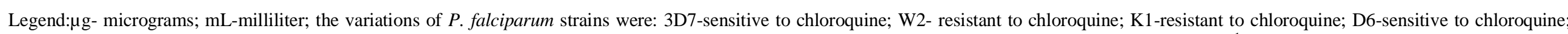

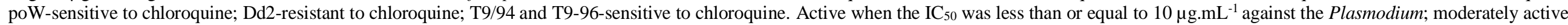
with an $\mathrm{IC}_{50}$ greater than $10 \mu \mathrm{g} . \mathrm{mL}^{-1}$ and less than $100 \mu \mathrm{g} \cdot \mathrm{mL}^{-1}$ and inactive with an $\mathrm{IC}_{50}$ greater than $100 \mu \mathrm{g} . \mathrm{mL}^{-1}$.*Assay was performed in vitro.

Source: Gomes ARQ et al., (2021). 
Figure 1. Chemical structures of quinones isolated from plants.

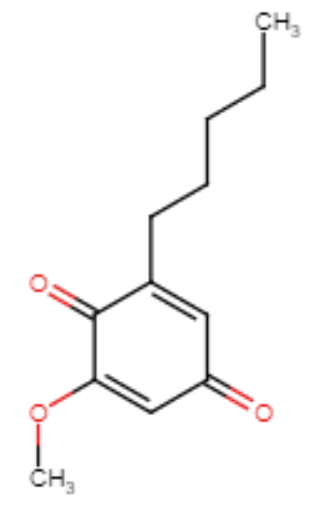<smiles>Cc1cc(=O)[nH]c2c1C(=O)c1ccccc1C2=O</smiles><smiles>COc1cccc2cc3c(c(O)c12)[C@H](C)OC3=O</smiles><smiles>CC1(C)CCC2=C(O1)c1ccccc1C(=O)C2=O</smiles><smiles>COc1cccc2c1C(=O)C1=C(C[C@H](C)O[C@H]1C)C2=O</smiles><smiles>Cc1cc(O)c2c(c1)C(=O)C(c1c(C)cc3c(c1O)C(=O)C=CC3=O)=CC2=O</smiles>

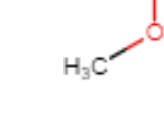<smiles>COc1cccc2c1C(=O)C1=C(C[C@H](C)O[C@H]1C)C2=O</smiles><smiles>COc1cccc2c1C(=O)c1oc(C(C)=O)cc1C2=O</smiles><smiles>CC(C)=CCC1=C(O)C(=O)c2ccccc2C1=O</smiles><smiles>CCCCCC1=CC(=O)C(CC=C(C)CCC=C(C)C)=C(OC(C)=O)C1=O</smiles><smiles>CC1(C)CCC2=C(O1)C(=O)c1ccccc1C2=O</smiles><smiles>CC(=O)c1cc2c(o1)C(=O)c1ccccc1C2=O</smiles>
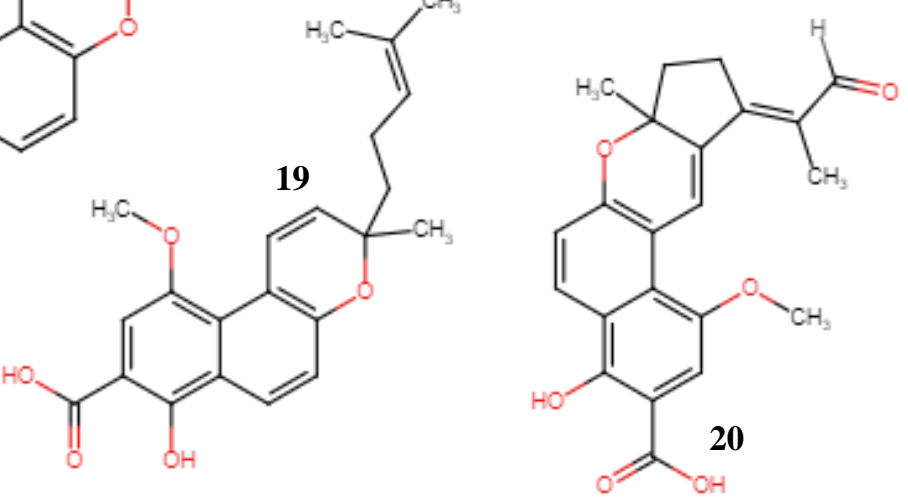


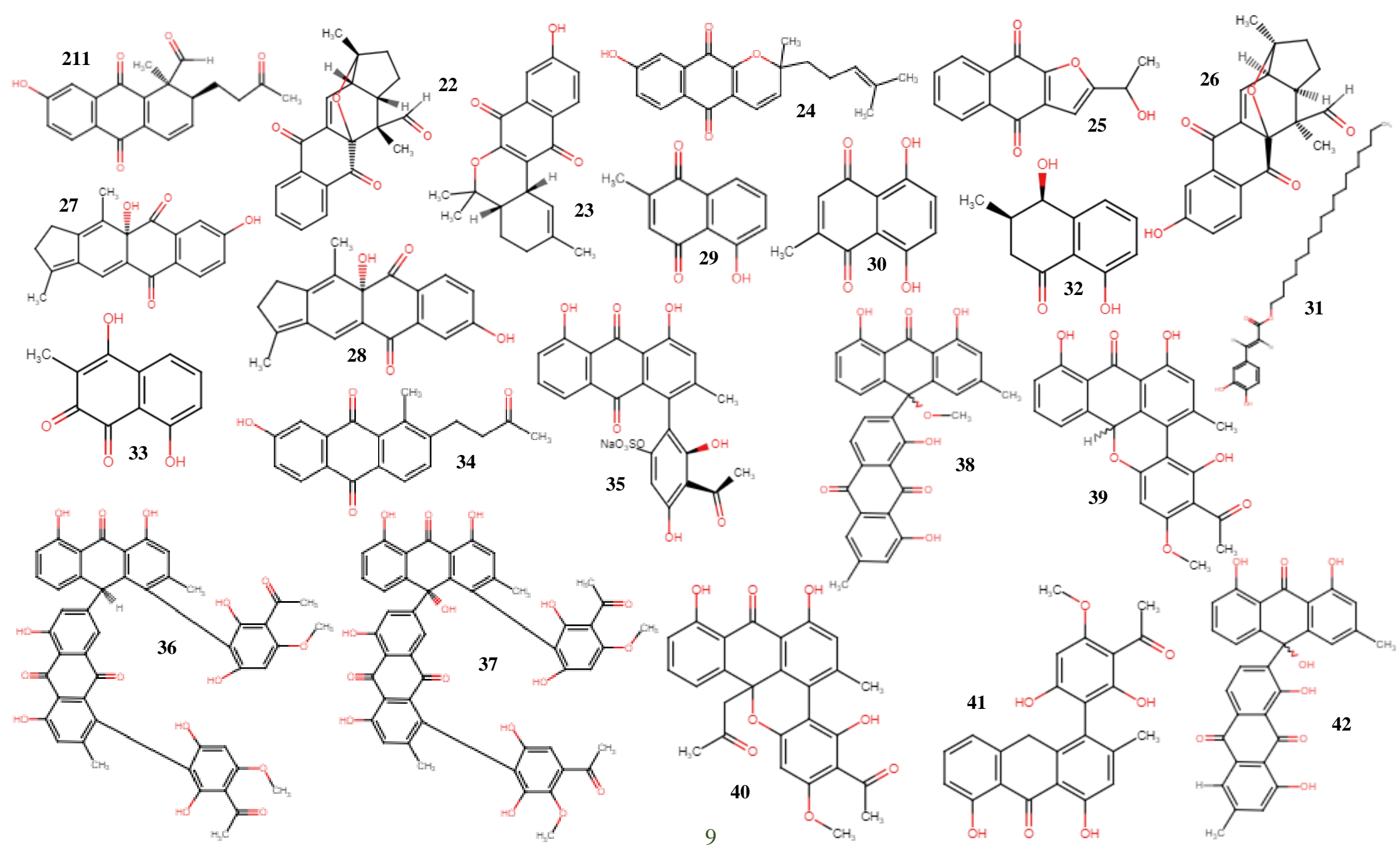



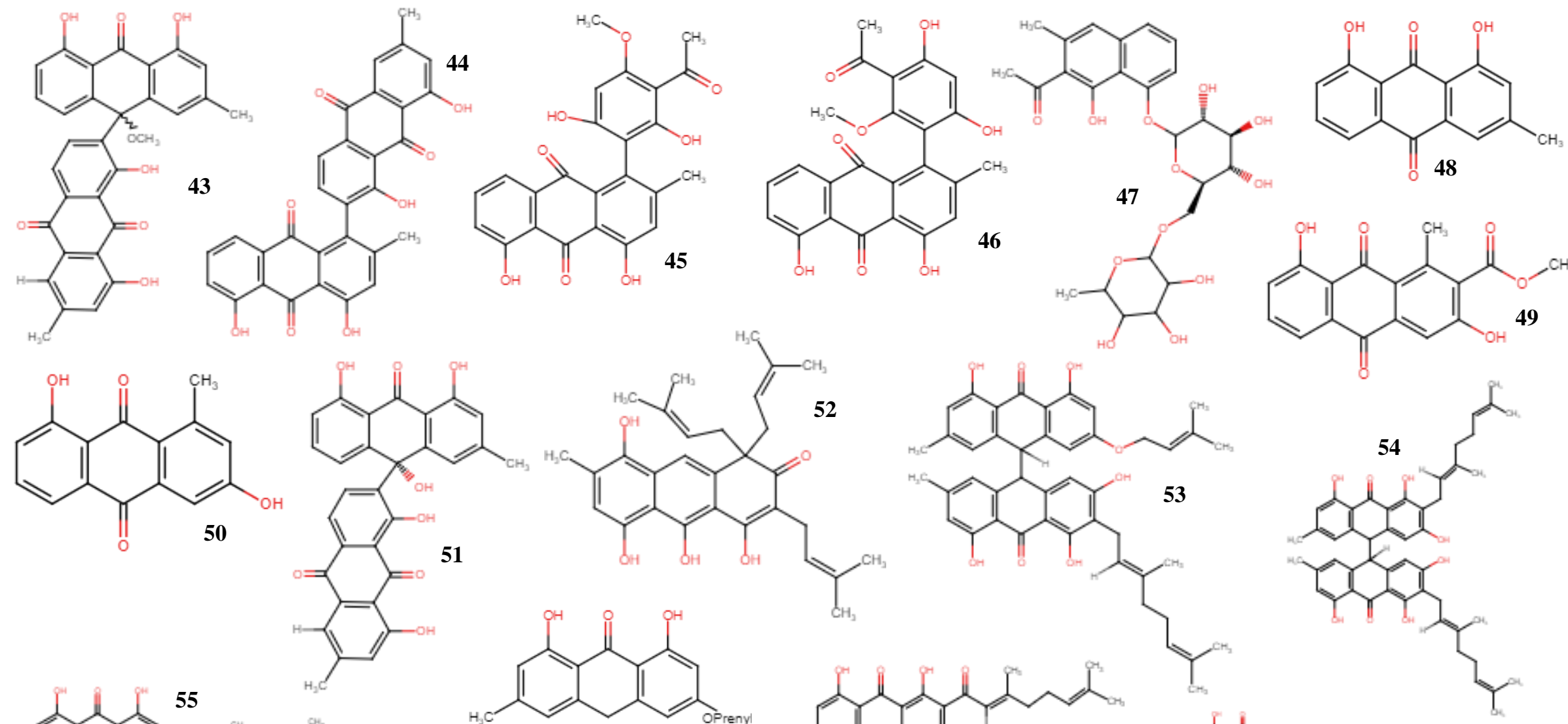

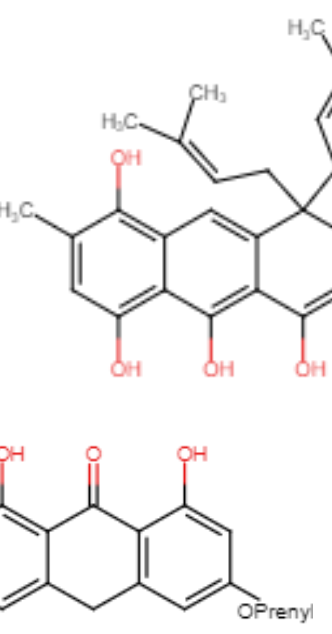

56
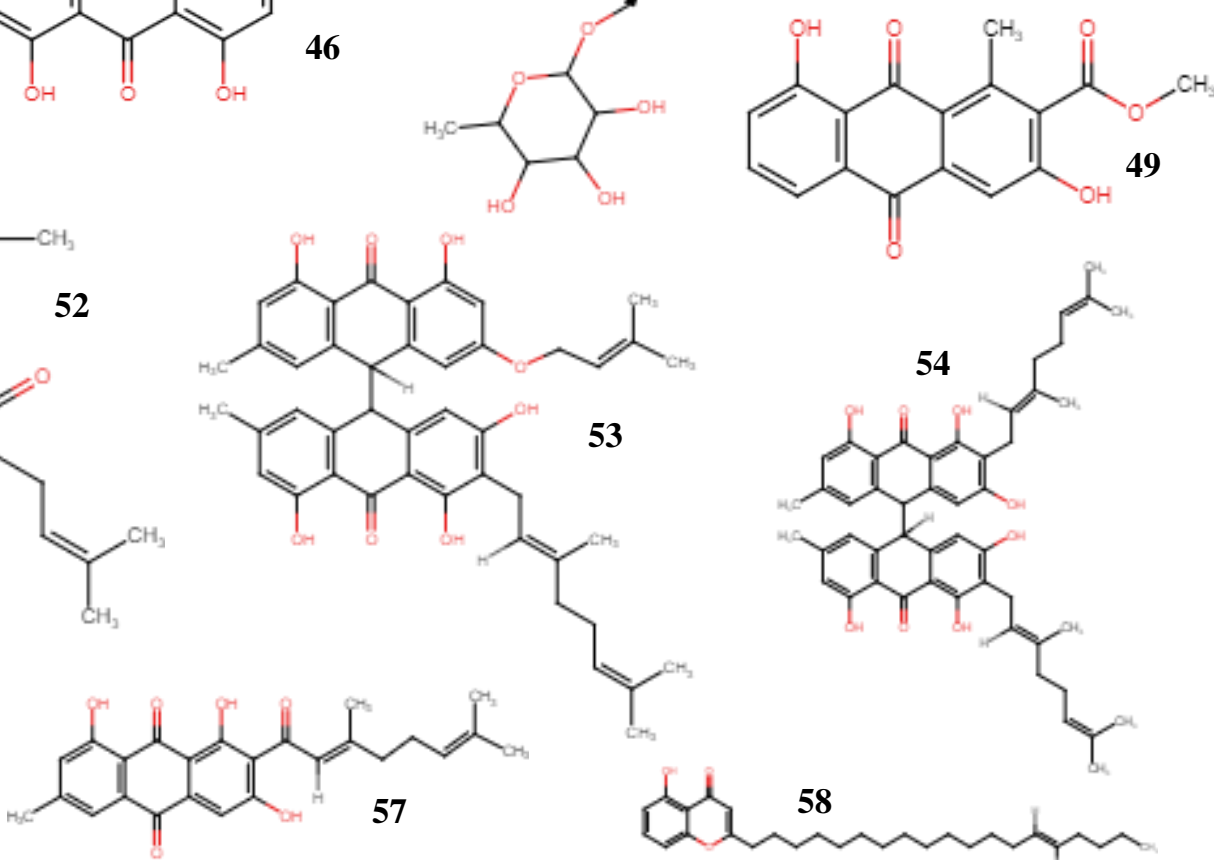

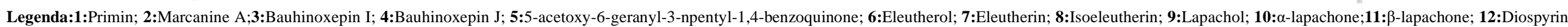

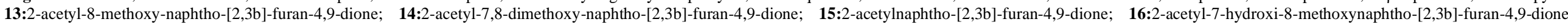

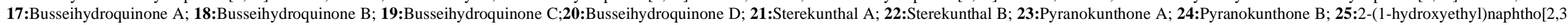

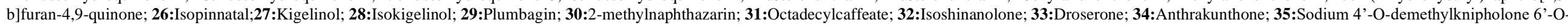

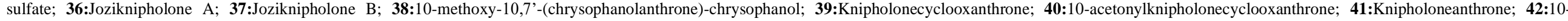

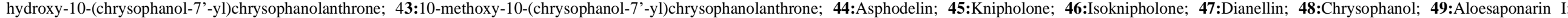

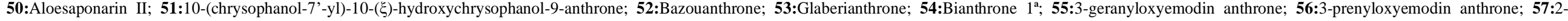
geranylemodin; 58:Peperovulcanone A

Source: Gomes ARQ et al., (2021). 


\section{Conclusion}

Quinones are promising as an antimalarial, however, there is a lack of in vivo studies for compounds belonging to the benzoquinone, anthraquinone and anthrax classes. In vitro studies, carried out with resistant $P$. falciparum clones, suggest that compounds belonging to these classes are promising antimalarials.

Regarding naphthoquinones, the compound 2-acetylnaphtho- [2,3b] -furan-4,9-dione presented the highest activity against Plasmodium berghei, and studies that aim to evaluate its safety should be prioritized. Without a doubt, the most studied naphthoquinone, promising as an antimalarial, is lapachol. For some biological activities, the lapachol ortho isomer $(\beta$ lapachone) is the most active and most cytotoxic form. In the present study, lapachol appears to be more promising than $\beta$ lapachone and $\alpha$-lapachone.

The pharmacological therapies used to treat malaria are a source of free radicals to fight the parasite, since it is known that the Plasmodium sp. is highly sensitive to such molecules. Thus, studies on the generation of free radicals in the treatment and development of new drugs in malaria are necessary, especially those for the characterization and isolation of compounds from medicinal plants and their metabolites, both in vitro and in vivo.

\section{Acknowledgments}

The authors are grateful for the financial support of the Commission for the Improvement of Higher Education Personnel (CAPES) and the Dean of Research and Graduate Studies-PROPESP / UFPA and CNPq-Universal (432458/20182).

\section{References}

Abdissa, D., Geleta, G., Bacha, K., \& Abdissa, N. (2017). Phytochemical investigation of Aloe pulcherrima roots and evaluation for its antibacterial and antiplasmodial activities. PLoS One, 12(3), e0173882. 10.1371/journal.pone.0173882

Abdissa, N., Induli, M., Akala, H. M., Heydenreich, M., Midiwo, J. O., Ndakala, A., \& Yenesew, A. (2013). Knipholone cyclooxanthrone and an anthraquinone dimer with antiplasmodial activities from the roots of Kniphofia foliosa. Phytochemistry Letters, 6(2), 241-245. 10.1016/j.phytol.2013.02.005

Aguiar, A. C. C., da Rocha, E. M., de Souza, N. B., França, T. C., \& Krettli, A. U. (2012). New approaches in antimalarial drug discovery and development: a review. Memorias do Instituto Oswaldo Cruz, 107(7), 831-845. 10.1590/S0074-02762012000700001

Barbosa, M. I., Correa, R. S., de Oliveira, K. M., Rodrigues, C., Ellena, J., Nascimento, O. R., \& Batista, A. A. (2014). Antiparasitic activities of novel ruthenium/lapachol complexes. Journal of inorganic biochemistry, 136, 33-39. 10.1016/j.jinorgbio.2014.03.009

Basco, L. K., de Pécoulas, P. E., Wilson, C. M., Le Bras, J., \& Mazabraud, A. (1995). Point mutations in the dihydrofolate reductase-thymidylate synthase gene and pyrimethamine and cycloguanil resistance in Plasmodium falciparum. Molecular and biochemical parasitology, 69, 135-138. 10.1016/01666851(94)00207-4

Birth, D., Kao, W. C., \& Hunte, C. (2014). Structural analysis of atovaquone-inhibited cytochrome bc 1 complex reveals the molecular basis of antimalarial drug action. Nature communications, 5(1), 1-11. 10.1038/ncomms5029

Boonphong, S., Puangsombat, P., Baramee, A., Mahidol, C., Ruchirawat, S., \& Kittakoop, P. (2007). Bioactive compounds from Bauhinia purpurea possessing antimalarial, antimycobacterial, antifungal, anti-inflammatory, and cytotoxic activities. Journal of natural products, 70(5), 795-801. 10.1021/np070010e

Borges, E. S., da Rocha Galucio, N. C., Veiga, A. S. S., Busman, D. V., de Almeida Lins, A. L. F., de Oliveira Bahia, M., \& Dolabela, M. F. (2020). Botanical studies, antimicrobial activity and cytotoxity of Eleutherine bulbosa (Mill.) Urb. Research, Society and Development, 9(11), e3369119992-e3369119992. $10.33448 /$ rsd-v9i11.9992

Bringmann, G., Mutanyatta-Comar, J., Maksimenka, K., Wanjohi, J. M., Heydenreich, M., Brun, R., \& Yenesew, A. (2008). Joziknipholones A and B: the first dimeric phenylanthraquinones, from the roots of Bulbine frutescens. Chemistry-A European Journal, 14(5), 1420-1429. 10.1002/chem.200701328.

Coutinho, J. P., Aguiar, A. C. C., Santos, P. A. D., Lima, J. C., Rocha, M. G. L., Zani, C. L., \& Krettli, A. U. (2013). Aspidosperma (Apocynaceae) plant cytotoxicity and activity towards malaria parasites. Part I: Aspidosperma nitidum (Benth) used as a remedy to treat fever and malaria in the Amazon. Memórias do Instituto Oswaldo Cruz, 108(8), 974-982. 10.1590/0074-0276130246

da Veiga, A. D. S. S., Brígido, H. P. C., Percário, S., do Rosário Marinho, A. M., \& Dolabela, M. F. (2020). Antileishmanial potential of alkaloids isolated from plants: an integrative review. Research, Society and Development, 9(10), e9119109334-e9119109334. 10.33448/rsd-v9i10.9334 
de Andrade-Neto, V. F., Goulart, M. O., da Silva Filho, J. F., da Silva, M. J., Maria do Carmo, F. R., Pinto, A. V., ... \& Krettli, A. U. (2004). Antimalarial activity of phenazines from lapachol, $\beta$-lapachone and its derivatives against Plasmodium falciparum in vitro and Plasmodium berghei in vivo. Bioorganic \& medicinal chemistry letters, 14(5), 1145-1149. 10.1016/j.bmcl.2003.12.069.

do Nascimento Brandão, D. L., Martins, M. T., Silva, A. O., Almeida, A. D., de Paula, R. C., de Oliveira, A. B., ... \& Dolabela, M. F. (2020). Anti-malarial activity and toxicity of Aspidosperma nitidum Benth: a plant used in traditional medicine in the Brazilian Amazon. Research, Society and Development, 9(10), e5059108817-e5059108817. 10.33448/rsd-v9i10.8817

do Nascimento, M. F. A., Borgati, T. F., de Souza, L. C. R., Tagliati, C. A., \& de Oliveira, A. B. (2020). In silico, in vitro and in vivo evaluation of natural Bignoniaceous naphthoquinones in comparison with atovaquone targeting the selection of potential antimalarial candidates. Toxicology and Applied Pharmacology, 115074. 10.1016/j.taap.2020.115074

El Hage, S., Ane, M., Stigliani, J. L., Marjorie, M., Vial, H., Baziard-Mouysset, G., \& Payard, M. (2009). Synthesis and antimalarial activity of new atovaquone derivatives. European journal of medicinal chemistry, 44(11), 4778-4782. 10.1016/j.ejmech.2009.07.021

Endale, M., Ekberg, A., Akala, H. M., Alao, J. P., Sunnerhagen, P., Yenesew, A., \& Erdélyi, M. (2012). Busseihydroquinones A-D from the Roots of Pentas bussei. Journal of Natural Products, 75(7), 1299-1304. 10.1021/np3002223

Feilcke, R., Arnouk, G., Raphane, B., Richard, K., Tietjen, I., Andrae-Marobela, K., \& Fobofou, S. A. (2019). Biological activity and stability analyses of knipholone anthrone, a phenyl anthraquinone derivative isolated from Kniphofia foliosa Hochst. Journal of pharmaceutical and biomedical analysis, 174, 277285. 10.1016/j.jpba.2019.05.065

Gamo, F. J., Sanz, L. M., Vidal, J., De Cozar, C., Alvarez, E., Lavandera, J. L., \& Garcia-Bustos, J. F. (2010). Thousands of chemical starting points for antimalarial lead identification. Nature, 465(7296), 305-310. 10.1038/nature09107

Gómez-Estrada, H., Gaitán-Ibarra, R., Díaz-Castillo, F., Pérez, H. A., \& Medina, J. D. (2012). In vitro antimalarial activity of fractions and constituents isolated from Tabebuia billbergii. Revista Cubana de Plantas Medicinales, 17(2), 172-180. http://scielo.sld.cu

Hughes, L. M., Lanteri, C. A., O’Neil, M. T., Johnson, J. D., Gribble, G. W., \& Trumpower, B. L. (2011). Design of anti-parasitic and anti-fungal hydroxynaphthoquinones that are less susceptible to drug resistance. Molecular and biochemical parasitology, 177(1), 12-19. 10.1016/j.molbiopara.2011.01.002

Hyde, J. E. (2002). Mechanisms of resistance of Plasmodium falciparum to antimalarial drugs. Microbes and Infection, 4(2), 165-174. 10.1016/s12864579(01)01524-6

Ichino, C., Soonthornchareonnon, N., Chuakul, W., Kiyohara, H., Ishiyama, A., Sekiguchi, H., \& Yamada, H. (2006). Screening of Thai medicinal plant extracts and their active constituents for in vitro antimalarial activity. Phytotherapy Research: An International Journal Devoted to Pharmacological and Toxicological Evaluation of Natural Product Derivatives, 20(4), 307-309. 10.1002/ptr.1850

Induli, M., Gebru, M., Abdissa, N., Akala, H., Wekesa, I., Byamukama, R., \& Yenesew, A. (2013). Antiplasmodial quinones from the rhizomes of Kniphofia foliosa. Natural product communications, 8(9), 1934578X1300800920. 10.1177/1934578X1300800920

Kumar, R., Musiyenko, A., \& Barik, S. (2003). The heat shock protein 90 of Plasmodium falciparum and antimalarial activity of its inhibitor, geldanamycin. Malaria Journal, 2(1), 30. 10.1186/1475-2875-2-30

Lenta, B. N., Devkota, K. P., Ngouela, S., Boyom, F. F., Naz, Q., Choudhary, M. I., \& Sewald, N. (2008). Anti-plasmodial and cholinesterase inhibiting activities of some constituents of Psorospermum glaberrimum. Chemical and Pharmaceutical Bulletin, 56(2), 222-226. 10.1248/cpb.56.222

Lenta, B. N., Ngouela, S., Boyom, F. F., Tantangmo, F., Tchouya, G. R. F., Tsamo, E., \& Connolly, J. D. (2007). Anti-plasmodial activity of some constituents of the root bark of Harungana madagascariensis L AM.(Hypericaceae). Chemical and pharmaceutical bulletin,55(3), 464-467. $10.1248 / \mathrm{cpb} .55 .464$

Likhitwitayawuid, K., Kaewamatawong, R., Ruangrungsi, N., \& Krungkrai, J. (1998). Antimalarial naphthoquinones from Nepenthes thorelii. Planta medica, 64(03), 237-241. 10.1055/s-2006-957417

Moreira, D. R., de Sá, M. S., Macedo, T. S., Menezes, M. N., Reys, J. R. M., Santana, A. E., \& Soares, M. B. (2015). Evaluation of naphthoquinones identified the acetylated isolapachol as a potent and selective antiplasmodium agent. Journal of enzyme inhibition and medicinal chemistry, 30(4), 615-621. $10.3109 / 14756366.2014 .958083$

Mutanyatta, J., Bezabih, M., Abegaz, B. M., Dreyer, M., Brun, R., Kocher, N., \& Bringmann, G. (2005). The first 6'-O-sulfated phenylanthraquinones: isolation from Bulbine frutescens, structural elucidation, enantiomeric purity, and partial synthesis. Tetrahedron, 61(35), 8475-8484. 10.1016/j.tet.2005.06.055

Nájera, J. A. (2001). Malaria control: achievements, problems and strategies. Parassitologia, 43(1-2), 1-89. https://apps.who.int/iris/handle/10665/66640

Ngemenya, M. N., Metuge, H. M., Mbah, J. A., Zofou, D., Babiaka, S. B., \& Titanji, V. P. (2015). Isolation of natural product hits from Peperomia species with synergistic activity against resistant Plasmodium falciparum strains. European Journal of Medicinal Plants, 77-87. 10.9734/EJMP/2015/13158

Noedl, H., Se, Y., Schaecher, K., Smith, B. L., Socheat, D., \& Fukuda, M. M. (2008). Evidence of artemisinin-resistant malaria in western Cambodia. New England Journal of Medicine, 359(24), 2619-2620. 10.1056/NEJMc080501

Onegi, B., Kraft, C., Köhler, I., Freund, M., Jenett-Siems, K., Siems, K., \& Eich, E. (2002). Antiplasmodial activity of naphthoquinones and one anthraquinone from Stereospermum kunthianum. Phytochemistry, 60(1), 39-44. 10.1016/s0031-9422(02)00072-9

Organización Panamericana de la Salud. Actualización Epidemiológica: Malaria en las Américas en el contexto de la pandemia de COVID-19. Washington, D.C.: OPS/OMS (2020), https://iris.paho.org/handle/10665.2/52288

Penna-Coutinho, J., Cortopassi, W. A., Oliveira, A. A., França, T. C. C., \& Krettli, A. U. (2011). Antimalarial activity of potential inhibitors of Plasmodium falciparum lactate dehydrogenase enzyme selected by docking studies. PloS one, 6(7), e21237. 10.1371/journal.pone.0021237 
Radwan, M. M., ElSohly, M. A., Slade, D., Ahmed, S. A., Wilson, L., El-Alfy, A. T., \& Ross, S. A. (2008). Non-cannabinoid constituents from a high potency Cannabis sativa variety. Phytochemistry, 69(14), 2627-2633. 10.1016/j.phytochem.2008.07.010

Richter, K., \& Buchner, J. (2001). Hsp90: chaperoning signal transduction. Journal of cellular physiology, 188(3), 281-290. 10.1002/jcp.1131

Silva, M. N. D., Ferreira, V. F., \& de Souza, M. C. B. (2003). Um panorama atual da química e da farmacologia de naftoquinonas, com ênfase na betalapachona e derivados. Química Nova, 26(3), 407-416. 10.1590/S0100-40422003000300019

Souza, N. B. D., de Andrade, I. M., Carneiro, P. F., Jardim, G. A., de Melo, I. M., da Silva Júnior, E. N., \& Krettli, A. U. (2014). Blood shizonticidal activities of phenazines and naphthoquinoidal compounds against Plasmodium falciparum in vitro and in mice malaria studies. Memórias do Instituto Oswaldo Cruz, 109(5), 546-552. 10.1590/0074-0276130603

Tasdemir, D., Brun, R., Yardley, V., Franzblau, S. G., \& Rüedi, P. (2006). Antituberculotic and antiprotozoal activities of primin, a natural benzoquinone: In vitro and in vivo studies. Chemistry \& biodiversity, 3(11), 1230-1237. 10.1002/cbdv.200690124

Theerachayanan, T., Sirithunyalug, B., \& Piyamongkol, S. (2007). Antimalarial and antimycobacterial activities of dimeric Naphthoquinone from Diospyros glandulosa and Diospyros rhodocalyx. CMU J Nat Sci, 6, 253-258. https://cmuj.cmu.ac.th/uploads/journal_list_index/490296517.pdf

Thomson, R. H. R. H. (2012). Naturally occurring quinones. Academic Press.

Vale, V. V., Cruz, J. N., Viana, G. M. R., Póvoa, M. M., Brasil, D. D. S. B., \& Dolabela, M. F. (2020). Naphthoquinones isolated from Eleutherine plicata herb: In vitro antimalarial activity and molecular modeling to investigate their binding modes. Medicinal Chemistry Research,29(3), 487-494. $10.1007 / \mathrm{s} 00044-019-02498-\mathrm{z}$

Van Hong, N., Amambua-Ngwa, A., Tuan, N. Q., Cuong, D. D., Giang, N. T. H., Van Dung, N., \& Erhart, A. (2014). Severe malaria not responsive to artemisinin derivatives in man returning from Angola to Vietnam. Emerging Infectious Diseases, 20(7), 1207. 10.3201/eid2007.140155

Waller, R. F., \& McFadden, G. I. (2005). The apicoplast: a review of the derived plastid of apicomplexan parasites. Current issues in molecular biology, 7, 5780. http://www.cimb.org

Weiss, C. R., Moideen, S. V., Croft, S. L., \& Houghton, P. J. (2000). Activity of extracts and isolated naphthoquinones from Kigelia pinnata against Plasmodium falciparum. Journal of Natural Products, 63(9), 1306-1309. 10.1021/np000029g

Winstanley, P. (2001). Modern chemotherapeutic options for malaria. The Lancet infectious diseases, 1(4), 242-250. 10.1016/S1473-3099(01)00119-0

Wongsrichanalai, C., Pickard, A. L., Wernsdorfer, W. H., \& Meshnick, S. R. (2002). Epidemiology of drug-resistant malaria. The Lancet infectious diseases, 2(4), 209-218. 10.1016/s1473-3099(02)00239-6

WHO: World Malaria Report. Geneva, World Health Organization (2019), https://www.who.int/malaria/publications/world-malaria-report-2019/en

Wube, A. A., Bucar, F., Asres, K., Gibbons, S., Rattray, L., \& Croft, S. L. (2005). Antimalarial compounds from Kniphofia foliosa roots. Phytotherapy Research, 19(6), 472-476. 10.1002/ptr.1635 